\title{
25. 離島と団地の幼児の運動能力の差翼について
}

岡山就实短大○宗高弘子, 京都大学 松浦義行, 矢掛商高 宗高平八

幼児の生活の中心が遊びと塄動であることから，諸能力のうちの運動能力が，遊び方や運動の仕方によつてどのよ うな発達を示すか地域差を中心拷察する。

標本は岡山県内の笠岡諸島飞属する鹤島と鉄工団地内の幼稚園児で, 年少男子 89女子 65, 年長男子 102女子 91合計 375である. 湘定には体位 4 項目と荤動能力13項目を取り上げ，45年 7 月〜9月飞実施した.

離島と団地の差異を年令男女別，年令差，性差の三点飞打いて大検定により検討した結果，年令男女別では年少男 子飞項目の差異がみられ，一項目を除いて離島が優れている，年令差では両標本共に長青の発育が著しく，体位全般 では $\mathrm{t}$ 榆定による有意差を示す項目が多いことから，団地の方が発育速度が大であると推定されるまた通動能力で は男女共に静的筋力，瞬発筋力を除くすべての進動能力領域において差異がみられることより，団地の園児の一年間 の生活経験が運動能力の発達に大きく影響しているものと思われる。これと対し離島の園児の一年間の生活経験は， 男子の筋持久力，女子の筋持久力，速度，運動協調能力などに有意な差を示す結果となつている．性差で崔島，団 地共に一定の傾向はみられず，運動協娚能力のまりつきとボール投にのみ著しい差異がみられ，女子はボールをつ き，男子はボールを投げる生活習慣が運動能力の差異として現れたのではないかと思われる。

\section{6. 山間部積雪時の児童の摃取栄蒦と発育}

信州大学教育学部保健体育科 吉 岡 利 治

自然環境の種々な条件が児童の発育に如何なる影響をむたらすかれついての研究の一環として豪雪地带を選び，こ の地方の児童の体格と冬期に扣ける坚童の摄取栄養の調查を行つた。調查対象は A地区として国鉄飯山線沿線の山間 部（冬期には積雪のため全く交通機関が閉される）及び積雪は多いが年中バス交通がほぼ確保されている国鉄大糸線 沿線の山間部地区の 2 ケ所である. 体格検查は 3，4，5年男女計 208 名，食䬣調查は男女13名計 3 日間実洞である. その結果，体格は舆野県平均と比較して両地区共大差は無いが傾向としてA地区児童が県平均よりも勝りB地区は県 平均よりも劣つていた。 一方摄取栄盖（3月上旬測定）では熱量及び蛋白質は所要量飞対しA地区 6〜 7\%, 6〜20

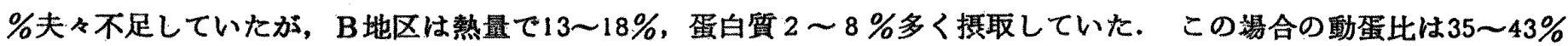
で化学価64 75, E/T 比2.5 2.7であつて両地区共摄取蛋白の栄菟価は比較的良質であると云える. これは最近の動 物性加工食品の普及によるすのと思われる。しかるK V.C 除をく他のビタミン類は両地区共不足して居り, 就中骨格 の発有飞必要な V.D は所要量の15〜20\%程度しか摃取されていなかつた。

以上の結果から体格のみならずより強い体力をあ期待するためには Ca の損取と共にビタミン類の 摄取を增すため 新鮮な野菜及び魚類の㠌取を多くすることが肝要であると思われる。

\section{7. ニユーギニア高地青少年の体格と逞動能力の発達 (2)}

立正女子大学 森 下 はる み ニューギニア高地青少年の体格と運動能力Kついて, 前回(19回大会発表, APA in OCEANIA, Vol. 4, No. 2) Kひきつづき、同じ地区の，上り未開な公立小学校児 161 名と前回の対象校児72名（男子182 名，女子51 名）飞つい $\tau$, 1969年9～10月に調查した.

項目は身長・体重・足跡・片是立ちと片足爪先立ちを開眠で20秒，ステッピングを30秒，3 分閒の踏台昇降テスト である. 踏台昇降には，三举プルスメーターKより，運動開始後 1 分と 2 分目から，運動後は 0 分， 1 分， 2 分， 3 分目から，それぞれ30秒閒の脈拍数を数えた。

結果についてみると，身長・体重は生活条件の未開な地区は，ひらりた地区の小学生に比し，身長で $3 \sim 5 \mathrm{~cm}$, 体 重で 3〜10ポンド括とる. また日本人児童と差はさらK大きい. 足跡について H. Clark の分類によれば，土ふまず のすくない I ・II 型が半数以上をしめ，足跡では扁平型が多い．しかし偏平足か否かはX線等による調査が必要であ ろう.ステッピングは日本人に比へおとり, 年令発達もすくない, 片足立ち, 片足爪先立ちの発達は日本人に比べ, はるがまさり，6才でほぼ90\%近い值をしめす、ステップテストでは，運動直後で，1 分值が120以下であり，心䑏 循環系の生理的予猶が大きいことがわかる，荤動後脈拍数について，文部省による得点に授算してみると，日本人よ ク,ほぼ10点以上まさつている. 